\title{
"THE GLORY OF THE NATION": BLACK SOLDIER-HISTORIANS AND THE CONTINUING AFRICAN AMERICAN STRUGGLE FOR A USABLE PAST
}

\author{
ROBERT COOK
}

UNIVERSITY OF SUSSEX

\begin{abstract}
Heated controversies in the United States over the 1619 Project's construction of a race-centered master narrative of American history highlight the need to locate public debates over this topic in historical context. This article analyzes the concerted efforts of two black Union veterans, George Washington Williams and Joseph T. Wilson, to remember African Americans' wartime military service at a critical moment in the progress of Civil War memory. By the late 1880 s the northern victors' account of the southern slaveholders' revolt against the US government was fading fast under the challenge of new, hegemonic narratives that deprived African Americans of significant agency in the "War of the Rebellion". The article contends that, while the two pioneer soldier-historians were unable to sustain a national memory of black men's military patriotism into the Jim Crow era, their innovative narrative strategies helped to lay the foundations of an effective black counter-memory of the Civil War period in the twentieth century.

Keywords: American Civil War; African Americans; US Colored Troops; war memory; counter-memory
\end{abstract}

DOI: $10.14712 / 23363231.2021 .2$

Robert Cook is emeritus professor of American history at the University of Sussex. E-mail: r.cook@sussex.ac.uk.

The author thanks David Brown, Adam Gilbert, the editors of this special number, and two anonymous referees for their helpful comments on a first draft of this article. 


\section{Introduction}

Heated debates in the United States over the New York Times Magazine's 1619 Project reveal the controversial nature of race-centered master narratives of the American past. The Project, intended to raise public understanding of the defining role of white supremacy in American history, has been criticized by a wide range of academics and politicians. Whereas progressive historians like Sean Wilentz contend that it ignores or downplays evidence of interracial cooperation during moments of social upheaval like the Revolution, the Civil War, the New Deal and the 1960s, President Donald Trump and his right-wing allies denounce it for undermining the orthodox story of the United States as a land of freedom, democracy and opportunity for all. ${ }^{1}$ Speaking in September 2020 to announce the creation of an alternative " 1776 Commission" to promote "patriotic education," Trump excoriated the 1619 Project as an example of the way the left "has warped, distorted and defiled the American story with deceptions, falsehoods and lies." 2 The new commission, declared a subsequent executive order, would give children the alternative narrative they required: "access to what is genuinely inspiring and unifying in our history" in order to generate "the informed and honest patriotism that is essential for a successful republic."3

This essay contributes to ongoing public debates over the development of race-centered narratives in the United States by contextualizing them in terms of the history of Civil War memory. Specifically, it examines the efforts of two pioneering African American soldier-historians, George Washington Williams and Joseph T. Wilson, to fix in American memory remembrance of the role played by black Union troops in the Civil War of 1861-1865. These attempts proved unsuccessful during the early phase of the Jim Crow era, the late nineteenth century when southerners restored white supremacy by replacing a society based on slavery with one grounded in de jure racial segregation. However, by highlighting the agency of African Americans, the black soldier-historians

1 Adam Serwer, "The Fight Over the 1619 Project Is Not About the Facts," The Atlantic, December 23, 2019, https://www.theatlantic.com/ideas/archive/2019/12/historians-clash-1619-proct/604093/. For a judicious assessment of the Project see Phillip W. Magnus, The 1619 Project: A Critique ([Great Barrington, MA]: American Institute for Economic Research, 2020).

2 Steven Nelson, "Trump reveals 1776 Commission, aimed at promoting 'patriotic education', New York Post, September 17, 2020, https://nypost.com/2020/09/17/trump-issues-1776-commission-to-promote-patriotic-education/.

3 Executive Order on Establishing the President's Advisory 1776 Commission, November 2, 2020, The White House, https://www.whitehouse.gov/presidential-actions/executive-order-establishing-presidents-advisory-1776-commission/. 
contributed significantly to the construction of a usable past for their race by influencing directly the twentieth-century work of the formidable intellectual and activist W.E.B. Du Bois who has been described accurately by historian David Blight as "a self-conscious creator of black counter-memory."4 Anchored by the conviction that ordinary black folk had played a central role in American history, this samizdat counter-memory did not achieve significant cultural influence in the United States until the advent of the civil rights and Black Power movements of the 1960s. ${ }^{5}$ While Trump's determination to disseminate an essentially white supremacist account of US history demonstrates the contested nature of any black counter-memory, the soldier-historians' texts are potent evidence of the fact that African Americans have always been leading players in a national past scarred from the outset by profound (though not always uniform or unchanging) white hostility toward people of color.

In April 1865 four years of internecine carnage ended with the decisive military triumph of the armed forces of the United States over those of the breakaway Confederacy. Victorious Unionists heralded their defeat of what they routinely called the southern "rebellion" and the concomitant destruction of slavery as proof that democratic republics were not the unstable polities that European conservatives presumed them to be. During the Reconstruction period (1863-1877), the US government - dominated initially by antislavery Republicans - embarked on a remarkable experiment in interracial democracy in the conquered South. Congress enfranchised liberated black men, 180,000 of whom had enlisted in the Union army, in the expectation that they would use their new political power to counteract the influence of their defeated rebel masters. During the 1870s, however, southern Democrats, many of them former Confederates, used violence and intimidation against African Americans and their white allies to destroy Republican party governments in the southern states. In the decades after Reconstruction, Democratic politicians restored white supremacy in the region by disfranchising black men, by implementing de jure racial segregation to strip African Americans of their dignity and constitutional rights, and

4 David W. Blight, “W.E.B. Du Bois and the Struggle for American Historical Memory," in History and Memory in African-American Culture, ed. Geneviève Fabre and Robert O’Meally (New York: Oxford University Press, 1994), 46. Although Blight discussed the work of Williams and Wilson in Race and Reunion: The Civil War in American Memory (Cambridge, MA: Belknap Press of Harvard University Press, 2001), 168-170, 193, 196, 197, 301, 322, he did not make any direct connections with Du Bois's scholarship.

5 I define "counter-memory" as an insurgent grand narrative constructed by subaltern individuals and collectivities to contest hegemonic master narratives designed by dominant social groups to help them maintain power in a given society. 
by helping to foster a potent memory of the Confederates' wartime experience (the so-called "Lost Cause") which provided a durable cultural framework for the oppression of black folk in the region. ${ }^{6}$

Although scholars disagree over the extent to which the Civil War eroded racism in the victorious North during the turbulent 1860 s, they generally concur that white northerners assisted the consolidation of Jim Crow by embracing a sentimental culture of sectional (North-South) reconciliation - a culture that was fostered by novelists' production of intersectional wartime romances and nostalgic tales of the plantation South as well as by the successful efforts of new mass-circulation magazines like Century to highlight the courage of the fighting men on both sides. ${ }^{7}$ Fostered by a range of factors including industrial growth, the attainment of an overseas empire, a yearning for national peace, and a widespread (though by no means universal) lack of empathy for the plight of southern blacks, the culture of reconciliation rapidly corroded the victors' memory of the Civil War as a people's struggle waged against the slaveholders' revolt by patriotic white and black Unionists. ${ }^{8}$ It did so by depicting the Civil War as

6 There is a substantial secondary literature on the Lost Cause. See especially Charles Reagan Wilson, Baptized in Blood: The Religion of the Lost Cause, 1865-1920 (Athens: University of Georgia Press, 1980); Gaines M. Foster, Ghosts of the Confederacy: Defeat, the Lost Cause, and the Emergence of the New South, 1865-1913 (New York: Oxford University Press, 1987); and Karen L. Cox, Dixie's Daughters: The United Daughters of the Confederacy and the Preservation of Confederate Culture (Gainesville: University Press of Florida, 2003).

7 Blight, Race and Reunion, 211-254; K. Stephen Prince, Stories of the South: Race and the Reconstruction of Southern Identity, 1865-1915 (Chapel Hill: University of North Carolina Press, 2014); Megan L. Bever, "Paths to Reconciliation: Northern Interracial Romances of the Civil War Era," Civil War History 60, No. 1 (March 2014): 32-57, doi: 10.1353/cwh.2014.0024. On northerners' growing embrace of reconciliatory culture after the Civil War, see also Nina Silber, The Romance of Reunion: Northerners and the South, 1865-1900 (Chapel Hill: University of North Carolina Press, 1993). Chandra Manning contends in What This Cruel War Was Over: Soldiers, Slavery, and the Civil War (New York: Alfred A. Knopf, 2007), 221, that, as a result of their encounters with slavery and the enslaved during the Civil War, "astonishing changes took place in many white Union men's ideas about slavery and eventually, if more fragilely, about racial equality." However, while Blight's Race and Reunion, posits a broad tightening of white supremacy in the US after the social upheavals of the Civil War era, leading authorities on the commemorative culture of white Union veterans after 1865 insist that their hostility toward slavery as an institution did not translate into support for civil rights. See Barbara A. Gannon, The Won Cause: Black and White Comradeship in the Grand Army of the Republic (Chapel Hill: University of North Carolina Press, 2011), 8, and Caroline Janney, Remembering the Civil War: Reunion and the Limits of Reconciliation (Chapel Hill: University of North Carolina Press, 2013), 17, 113.

8 There is no comprehensive account of the Unionist strain of historical memory but for concise assessments see Earl J. Hess, Liberty, Virtue, and Progress: Northerners and Their War for the Union (New York: Fordham University Press, 1997), 103-127; Barbara A. Gannon, Americans Remember Their Civil War (Santa Barbara: Praeger, 2017), 19-36, and Robert J. Cook, Civil War Memories: Contesting the Past in the United States since 1865 (Baltimore: Johns Hopkins University Press, 
a tragic intra-familial conflict fought between white brothers motivated by different yet authentically American principles including, on the southern side, the rights of the individual states under the original Constitution of 1787. Not unlike Trump's "patriotic" history, this avowedly consensual but highly selective narrative bolstered racial oppression in the United States by promoting public amnesia about African Americans' wartime service on behalf of the republic.

\section{Black Soldier-Historians Remember the Civil War}

George Washington Williams and Joseph Wilson intervened in fractious public debates over the evolving meaning of the Civil War by reminding Americans, black as well as white, that Unionists like themselves had fought an ideological struggle to defeat the Confederates and render the United States a genuine interracial democracy. Their texts, Williams' A History of the Negro Troops in the War of the Rebellion 1861-1865 (1887) and Wilson's The Black Phalanx: African American Soldiers in the War of Independence, the War of 1812, and the Civil War (1887), were published during a decisive phase in American historical memory when Unionists' antisouthern and antislavery narrative was being subjected to growing pressure from both the South's Lost Cause and the cloying national culture of sectional reconciliation. ${ }^{9}$

2017), 69-94. Matthew E. Stanley, Civil War and Reunion in Middle America (Urbana: University of Illinois Press, 2017), illuminates the conservative and racially prejudiced nature of Unionist commemorative culture in the lower North. For a northern state study that highlights anti-racism as a significant factor in Unionists' memory work in the upper Midwest, see Robert J. Cook, "A War for Principle? Shifting Memories of the Union Cause in Iowa, 1865-1916," Annals of Iowa 74, No. 3 (Summer 2015): 221-262, doi: 10.17077/0003-4827.12211. Although white northerners were, as David Blight contended in Race and Reunion, increasingly supportive of sectional reconciliation over time, historians have shown that the process of reconciliation was far from smooth and heavily contested by influential groups in northern society including many Union veterans and Republican leaders. On this theme see John R. Neff, Honoring the Civil War Dead: Commemoration and the Problem of Reconciliation (Lawrence: University Press of Kansas, 2005); Janney, Remembering; and M. Keith Harris, Across the Bloody Chasm: The Culture of Commemoration Among Civil War Veterans (Baton Rouge: Louisiana State University Press, 2014). For an assessment of modern scholarship on sectional reconciliation see Robert J. Cook, "The Quarrel Forgotten: Toward a Clearer Understanding of Sectional Reconciliation," Journal of the Civil War Era 6, No. 3 (September 2016): 413-436, doi: 10.1353/cwe.2016.0052.

9 George Washington Williams, A History of the Negro Troops in the War of the Rebellion 1861-1865 (New York: Harper and Brothers, 1887); Joseph T. Wilson, The Black Phalanx: African American Soldiers in the War of Independence, the War of 1812, and the Civil War (Hartford: American Publishing Company, 1887). 
These pioneering texts reflected the fact that their authors were of mixedrace parentage and born free (Wilson in 1837 and Williams in 1849) in a society whose culture and politics were dominated by the existence of slavery. ${ }^{10}$ After leaving his home state of Virginia at an early age, Wilson attended school in Massachusetts before working on a whaling ship in the South Pacific and a railroad construction gang in Chile. Williams received only a limited education while growing up in Pennsylvania and developed a taste for adventure that never left him. Many free blacks during the 1850 s embraced the idea of emigrating to Liberia because domestic race relations were so dismal. ${ }^{11}$ But after President Abraham Lincoln, keenly aware that attacking southern slavery would assist the Union war effort, issued the Emancipation Proclamation in January 1863, the US government enlisted growing numbers of African Americans into the Union army as US Colored Troops (USCT) to suppress the slaveholders' rebellion. Former slaves constituted the bulk of these recruits but a minority were free-born blacks like Joseph Wilson and George Washington Williams, hopeful that a new day was dawning for people of color in America.

Wilson had a particularly tough war. He enlisted first as a private in the 2nd Louisiana Native Guard (later reorganized as the 74th USCT), contracted chronic diarrhea and was honorably discharged in September 1863. He then reenlisted in the 54th Massachusetts Infantry and was badly wounded at the battle of Olustee in Florida, one of several engagements where Confederates murdered captured black troops on the field and where, in the eyes of many prejudiced northern whites, black men won their spurs.

Williams' war service is shrouded in a degree of mystery but, according to his biographer John Hope Franklin, he enlisted late in the war and served in the Union army's 41st US Colored Infantry on the bloody eastern front in Virginia. Although wounded during the Petersburg campaign in September 1864, he recovered to see the city's surrender the following April. After the war ended, he joined the republican forces of Benito Juárez in Mexico to depose the French-imposed emperor Maximilian.

${ }^{10}$ For biographical information on these authors see John Hope Franklin, George Washington Williams: A Biography (Chicago: University of Chicago Press, 1985); John David Smith, Introduction to A History of Negro Troops in the War of the Rebellion, by George Washington Williams (1887; reprinted New York: Fordham University Press, 2012), ix-xxxvi; Elizabeth Varon and Dictionary of Virginia Biography, "Joseph T. Wilson (1837-1890)" in Encyclopedia Virginia, https://www. encyclopediavirginia.org/Wilson_Joseph_T_1837-1890.

11 Peter Kolchin, American Slavery $1619-18 \overline{7} 7$ (New York: Hill and Wang, 1993), 84-85. 
Ambitious and talented, both men worked tirelessly after leaving the army to try and cement the Union triumph to which they had contributed personally. This required them to overcome any personal doubts they had about the capabilities of the freedpeople and to engage as Republicans in Reconstruction-era politics to promote equal rights under the law for all African Americans.

Joseph Wilson was a prominent member of the Republican party in Norfolk, Virginia. As well as helping to establish a local black Union Club to press the case for African American suffrage on the grounds of the race's demonstrable wartime loyalty to the US government, he edited several newspapers in the town and continued to campaign vigorously for equal rights even after white Conservatives and Democrats regained power in the state during the early years of Reconstruction. A stalwart Republican hostile to cooperation with white Readjusters who opposed Democratic party rule in the state, he was a committed opponent of white supremacy. "Injustice and wrong," he told an Emancipation Day crowd in Norfolk in 1885, "seems [sic] to have been one of the principal sciences in the white man's civilization." 12 Wilson moved to the state capital, Richmond, in the same year and participated in working-class activism there until his premature death in 1891.

After his exploits in Mexico, George Washington Williams reenlisted in the US army in 1867 only to be discharged the following year after receiving a gunshot wound in an accident. He then undertook theological training, made himself fully literate, and became a Baptist preacher in Boston. Stirred by news of racist violence in the South, including the brutal massacre of more than 150 blacks in Colfax, Louisiana, in April 1873, he helped to organize a mass meeting to condemn the killings and demand congressional action to prevent more of them. ${ }^{13}$ In July 1875 he secured financial support from leading black and white abolitionists to set up a new newspaper, The Commoner, intended to foster the growth of free-labor values like thrift and self-reliance among the freedpeople. During the fall he made a speaking tour of the South that, taking place as it did in the midst of widespread white terrorism in Mississippi, further heightened his awareness of the ex-Confederates' determination to restore white supremacy by force.

12 Quoted in W. Fitzhugh Brundage, The Southern Past: A Clash of Race and Memory (Cambridge, MA: Belknap Press of Harvard University Press, 2005), 96.

${ }^{13}$ Franklin, George Washington Williams, 23, contends that the Colfax massacre had "a profound effect" on Williams. LeeAnna Keith, The Colfax Massacre: The Untold Story of Black Power, White Terror, and the Death of Reconstruction (New York: Oxford University Press, 2007) is a sobering account of this event. 
When The Commoner failed for lack of subscribers, Williams relocated to a church in Cincinnati to begin a new phase of his eventful career. Motivated by the widespread discrimination confronting Ohio's black population and assisted by his contacts with Union veterans of both races, he became an active Republican - one of the few African Americans who supported President Rutherford B. Hayes's conciliatory policy toward the defeated South (in part because of his strong desire for political patronage). However, although he became the first African American to be elected to the state legislature, the new Democratic president, Grover Cleveland, curtailed his political ambitions in 1885 by withdrawing his appointment as US minister to Haiti before he could reach Port-auPrince. From this point on, he devoted his time not only to writing history but also to garnering and disseminating information about the African slave trade. He was the first westerner to report the brutal treatment of the Congolese in the personal fiefdom of King Leopold II of Belgium and died in England while writing a book on this issue in 1891 .

The two Union veterans embarked on their histories in the immediate aftermath of Reconstruction. Williams gave early evidence of his intentions in Cincinnati on July 4, 1876 when he delivered a powerful centennial address centered on the view that the black man had been "his own deliverer, the defender of the Union" during the Civil War. ${ }^{14}$ This effort induced him to undertake deeper research into the African American past - research that culminated in publication of his two-volume History of the Negro Race in America in $1883 .{ }^{15}$ An anonymous and rather patronizing reviewer in The New York Times deemed the 190 pages on black troops by far the most "instructive and interesting" portion of the text and suggested that "it would probably be a good thing for author and publisher to republish it" as a single narrative. ${ }^{16}$ Williams soon embarked on his History of the Negro Troops in the War of the Rebellion - a more comprehensive treatment of this topic based on a wide range of archival and printed sources as well as interviews with black veterans - which was published four years later. By chance this book appeared in the same year as Joseph Wilson's Black Phalanx. Together, these works provide scholars with a unique opportunity to assess how black soldier-historians used their race's Civil War experience to construct a usable past in an era characterized by growing white amnesia about the role of black folk in the Civil War as well as by mounting oppression evidenced by the escalating

\footnotetext{
${ }^{14}$ Quoted in Smith, Introduction to A History of Negro Troops, xiv.

15 George Washington Williams, History of the Negro Race in America from 1619 to 1880, 2 vols. (New York: G.P. Putnam's Sons, 1882-1883).

16 "New Publications: The Negro Race," The New York Times, March 11, 1883.
} 
disfranchisement of southern black men and the US Supreme Court's ruling in the Civil Rights Cases (1883) that Congress could not protect African Americans from private discrimination under the Fourteenth Amendment.

Williams and Wilson were scholar-activists. They wrote their books because they believed that the faltering progress of equal rights was intrinsically connected to the fact that public remembrance of blacks' wartime military service was limited and waning, especially outside the confines of veterans' groups like the Grand Army of the Republic (GAR), the partially integrated Union ex-servicemen's organization to which they both belonged. ${ }^{17}$ By the late 1880 s, triumphant northerners had written many accounts of the Union cause in the form of national epics, regimental and local histories, and individual memoirs. ${ }^{18}$ But writing in 1885 Thomas J. Morgan, a white officer in a wartime black regiment, observed that "history has not yet done justice to the share borne by colored soldiers in the war for the Union." 19 Williams concurred fully with this judgment, noting that most Unionist texts gave little space to the role played by African American soldiers in the Civil War. Their record, he wrote, "was not only the proud and priceless heritage of a race, but the glory of a nation," yet their "appearance ... in the hundreds of histories of the war has always been incidental." He added, "These brave men have had no champion, no one to chronicle their record, teeming with interest and instinct with patriotism." ${ }^{20}$ Members of Wilson's own GAR post urged him to write a full-blown history of the USCT. ${ }^{21}$ He bemoaned the fact that black soldiers' "devotion" to their country had not only "been unappreciated" but that it had "also failed to receive a fitting commemoration in [the] pages of national history." 22 Both authors, then, were pursuing an urgent and ambitious goal: to fill a growing hole in their nation's memory of the Civil War before it was too late.

There are several reasons why most Unionist texts devoted minimal attention to the military contribution of Colored Troops. One was the fact that USCT units came relatively late to the war and did not participate in most of the conflict's major engagements until the siege of Petersburg in $1864-65 .{ }^{23}$ But per-

17 On the GAR see especially Stuart McConnell, Glorious Contentment: The Grand Army of the Republic, 1865-1900 (Chapel Hill: University of North Carolina Press, 1992) and Gannon, The Won Cause.

18 On soldier texts of the Civil War see Blight, Race and Reunion, 140-210.

19 Thomas J. Morgan, Reminiscences of Service with Colored Troops in the Army of the Cumberland, 1863-65 (Providence, RI: Society of the Army of the Cumberland, 1885), 50.

20 Williams, History of Negro Troops, xiv, 328.

${ }^{21}$ Wilson, Black Phalanx, unnumbered preface.

22 Ibid., 460.

23 Modern histories of these servicemen include Benjamin Quarles, The Negro in the Civil War (Boston: Little, Brown and Company, 1953); Dudley Taylor Cornish, The Sable Arm: Negro Troops 
haps the most important reason is that Unionist histories were written almost exclusively by white men who, some USCT officers like Thomas Morgan aside, did not regard the black contribution to the national cause as significant as their own, even while they often acknowledged the value of black people's loyalty to the government during the war. Few free-born or liberated African Americans, moreover, had the financial resources or connections needed to research, write and secure publication of USCT histories. Most black Union veterans lived in poverty and as a result died earlier than their white comrades. ${ }^{24}$ While often keen to mark their wartime sacrifices, they did so mainly by attending Memorial Day rituals and parades rather than by leaving more tangible reminders of their service such as memoirs and monuments. ${ }^{25}$

A close reading of the two soldier-historians' books reveals a common emphasis on six key themes: the manly courage of loyal black troops, the positive impact of their patriotic service on prejudiced white northerners, the capacity of southern whites for barbarism, the black troops' self-restraint when confronted by Confederate brutality, the virtue of race pride, and the importance for the group and the wider nation of remembering the sacrifice of the USCT in the Civil War.

Both authors supplied evidence of the bravery and patriotism of armed black men in the 1860s by detailing the latter's involvement in a range of military engagements fought on behalf of the US government in the second half of the late conflict. They made it clear that USCT regiments' courage under fire could have been predicted because black soldiers had been deployed not only by whites in America since the Revolutionary War of the 1770s and 1780s, but also by civilizations dating back to Egypt in ancient times. However, their narratives gave pride of place to the masculine courage of African American soldiers in the Civil War - even in putatively glorious failures such as the attacks at Port Hudson and Fort Wagner in 1863 and the battles of the Crater and Olustee in

in the Union Army, 1861-1865 (New York: Longmans, 1956); Joseph Glathaar, Forged in Battle: The Civil War Alliance of Black Soldiers and White Officers (New York: The Free Press, 1990); Noah Andre Trudeau, Like Men of War: Black Troops in the Civil War, 1862-1865 (Boston: Little, Brown, 1998); William A. Dobak, Freedom by the Sword: The U.S. Colored Troops, 1862-1867 (Washington, DC: Center of Military History, US Army, 2011); John David Smith, Lincoln and the U.S. Colored Troops (Carbondale: Southern Illinois University Press, 2013).

24 The many hardships confronting black veterans after the Civil War are detailed in Donald R. Shaffer, After the Glory: The Struggles of Black Civil War Veterans (Lawrence: University Press of Kansas, 2004).

25 On the commemorative culture of African Americans after the Civil War see especially Brundage, Southern Past, 55-104; Kathleen Ann Clark, Defining Moments: African American Commemoration \& Political Culture in the South, 1863-1913 (Chapel Hill: University of North Carolina Press, 2005). 
1864. Williams, for example, recounted how the "gallant" 54th Massachusetts had driven across the defensive ditch at Fort Wagner outside Charleston, South Carolina, and planted its flag on the battery's parapet before being cut down by the defending Confederates. "The appalling list of casualties," he wrote, "shows how bravely this Negro regiment had done its duty." 26 Wilson concurred. "The heroic courage displayed by the gallant Phalanx at the assault upon Fort Wagner," he insisted, "was not surpassed by the Old Guard at Moscow."27

Less predictable than such boasting (which was more than matched by white veterans) was the willingness of the two soldier-historians to stiffen their accounts of black courage under fire with occasional evidence of white Union cowardice. Both men took care in their books to acknowledge the support that white officers gave to their black troops. Williams described the 54th Massachusetts' patrician colonel, Robert Gould Shaw (who died with his men at Fort Wagner), as "brave, beautiful, and heroic," while Wilson actually dedicated his book to the white officers of black regiments. ${ }^{28}$ Yet when it came to describing the army's desperate and ultimately unsuccessful rearguard defense of Millikens Bend, an isolated Union post on the Mississippi River in June 1863, neither historian had any qualms contrasting the bravery of the USCT with the cowardice of their white peers. ${ }^{29}$ For Williams "the unimpeachable valor of the Negro troops" in this action would "remain a priceless heritage of the race for whose freedom they mostly contended." ${ }^{30} \mathrm{He}$, like Wilson, left readers to compare this heroic conduct with that of a white regiment which fled the scene in disarray.

The books were not just catalogues of black valor in defeat. Tens of thousands of USCT participated in the Union army's decisive efforts to bring the war to a successful conclusion in Virginia in late 1864 and early 1865 . Williams emphasized their role in several prominent actions around the strategically vital railroad hub of Petersburg, including their successful assault on Fort Harrison, which he hailed as "a brilliant and daring piece of work," and on Fort Gregg, which precipitated the city's surrender and the final collapse of the nearby

\footnotetext{
26 Williams, History of Negro Troops, 195, 199.

27 Wilson, Black Phalanx, 257. Wilson was referencing the actions of Napoleon's elite Old Guard troops in the emperor's Russian campaign of 1812. On the Union attack on Fort Wagner and its reception in the wartime North see James M. McPherson, Battle Cry of Freedom: The Civil War Era (New York: Oxford University Press, 1988), 686-687.

28 Williams, History of Negro Troops, 195; Wilson, Black Phalanx, unnumbered dedication page.

29 The Confederate assault on Millikens Bend and its later ramifications are detailed in Linda Barnickel, Milliken's Bend: A Civil War Battle in History and Memory (Baton Rouge: Louisiana State University Press, 2013).

30 Williams, History of Negro Troops, 228.
} 
Confederate capital, Richmond. ${ }^{31}$ The two historians also detailed the contribution and effectiveness of USCT units in the Appomattox campaign of April 1865 which culminated in the defeat of General Robert E. Lee's Army of Northern Virginia and presaged the end of the southern rebellion. ${ }^{32}$

Crucial to both narratives were their architects' insistence that black men's bravery in defense of the Union had reduced racial prejudice in the 1860s. Williams and Wilson openly conceded that at first many northerners had opposed arming African Americans and both men also noted that many white Union troops had been far from welcoming when they were enlisted. Wilson, for example, observed that it was "unpleasant ... to record that the black soldiers were subjected to many indignities, and suffered much at the hands of their white fellow comrades in arms." 33 However, he and Williams argued that the conduct of USCT in engagements like Fort Wagner had altered the racial views of many whites in the military. The courage of the 54th Massachusetts, observed Wilson, "completely removed any prejudice that had been exhibited toward negro troops in the Department of the South." ${ }^{34}$ Williams stated that initially "the faintest intimation that Negroes should be employed as soldiers in the Union Army was met with derision" but, he continued, once military necessity had impelled the Lincoln administration to start enlisting black men, the USCT proved their worth in battle and thereby brought about a sea-change in white attitudes. He singled out the failed assault on Port Hudson in May 1863 as an event that "completely revolutionized" military sentiment in the western theater "respecting the Negro as a man and a soldier." 35

To prove that black martial prowess on the battlefield had eroded prejudice in the 1860s, the two authors quoted liberally from white commanders like Griffin Stedman and Nathaniel Banks, who had publicly commended black soldiers for their conduct under fire, and government officers such as Secretary of War Edwin Stanton who asserted that, "[t]he hardest fighting [at Petersburg] was done by the black troops." 36 Williams found the postwar testimony of controver-

31 Ibid., 252, 298. On the significant contribution of the USCT to the ultimately decisive Petersburg campaign see Elizabeth R. Varon, Armies of Deliverance: A New History of the Civil War (New York: Oxford University Press, 2019), 386, 387.

32 According to Varon, six USCT regiments "played a key role in the last day's fighting [at Appomattox]." Elizabeth R. Varon, Appomattox: Victory, Defeat, and Freedom at the End of the Civil War (New York: Oxford University Press, 2013), 93.

33 Wilson, Black Phalanx, 207.

34 Ibid., 264.

35 Williams, History of Negro Troops, 221.

36 Ibid., 320 . 
sial Massachusetts congressman and former Union general Benjamin F. Butler particularly useful. He told readers how Butler, a onetime white supremacist Democrat who became a Radical Republican, had supported passage of a civil rights bill in the 1870s by conjuring vivid memories of how, after an assault during the Petersburg campaign, he had seen the corpses of hundreds of his black troops who had "laid down their lives" for the American flag. "[A]s I rode along among them ...," Butler remembered purposefully,

and as I looked on their bronzed faces upturned in the shining sun as if in mute appeal against the wrongs of the country for which they had given their lives, and whose flag had only been to them a flag of stripes on which no star of glory had ever shone for them - feeling I had wronged them in the past and believing what was the future of my country to them - among my dead comrades there I swore to myself a solemn oath: "May my right hand forget its cunning, and my tongue cleave to the roof of my mouth, if I ever fail to defend the rights of those men who have given their blood for me and my country this day and for their race forever ..." 37

It was not just the capacity of the black troops' sacrifice to corrode Butler's antebellum racism that gave the congressman's testimony particular force. Williams knew that reconciliatory sentiment was building in the 1880 s and that southern Democrats, abetted by the Supreme Court, were steadily eroding African Americans' war-born rights. ${ }^{38}$ Reminding readers of Butler's evocative comments imparted urgency as well as legitimacy and poignancy to his narrative.

Although the two chroniclers of the black martial experience took care not to oppose sectional reconciliation in principle, their texts included material that ran counter to prevailing racial assumptions in the late nineteenth century - assumptions that equated whiteness with civilization and blackness with barbarism. In doing so they remembered a unique period in American history when, during the 1850s and 1860s, northern whites had equated the institution of slavery with southern barbarism, violence and treason. The Confederates' well-documented massacre of Colored Troops at Fort Pillow in April 1864 loomed large in both books. ${ }^{39}$ Using testimony taken by members of a Republi-

37 Ibid., 255-256.

38 In 1883 the US Supreme Court in the Civil Rights Cases significantly narrowed the scope of the Fourteenth Amendment (passed by congressional Republicans in 1867 and ratified a year later) to protect liberated blacks from discrimination.

39 On the Fort Pillow massacre and its memory in American history see John Cimprich, Fort Pillow, a Civil War Massacre, and Public Memory (Baton Rouge: Louisiana State University Press, 2005). 
can-dominated congressional committee after the massacre, Williams described how black soldiers, knowing that their opponents would show them no mercy if they surrendered, had fled toward the Tennessee River only to be cut down mercilessly. Lest readers be unsure of the extent to which this incident amounted to "[o]ne of the most cruel exhibitions of Confederate malice," he added that many of the wounded had tried to feign death "but were revived by cruel kicks and blows, compelled to rise to their knees, and then shot." ${ }^{40}$ Some wounded African Americans, he asserted, had been buried alive. Wilson illustrated his account of the "indiscriminate slaughter" at Fort Pillow with a graphic drawing of the massacre which can only have reminded sympathetic readers that the contemporary oppression of the freedpeople, soon to be underscored by a rapid increase in anti-black lynching, had its roots in white southerners' unceasing determination to subordinate African Americans by any means necessary. ${ }^{41}$ Williams used the Confederates' brutal treatment of black prisoners of war to cement the point that readers should resist any temptation to regard the country's recent enemies generously - as misguided brothers engaged in a contest of conflicting American principles. Confederate prisons, he wrote, were "places of torture wherein every species of cruelty was perpetrated.... Christian civilization the world over will rejoice that such a cause has perished from among the governments of mankind." 42

The two authors bolstered their reminders of southern white barbarism with evidence of the Colored Troops' self-restraint, a characteristic traditionally linked in the minds of northerners with civilization and codified in the principles of nineteenth-century warfare. ${ }^{43}$ Such evidence, of course, was selective. The USCT were not plaster saints. Determined to avenge atrocities inflicted on their comrades, they did commit war crimes in a handful of Civil War engagements, notably at the battle of Jenkins' Ferry, Arkansas, in April 1864 and Fort Blakely outside Mobile the following spring. ${ }^{44}$ Joseph Wilson conceded black soldiers'

40 Williams, History of Negro Troops, 257, 262.

${ }^{41}$ Wilson, Black Phalanx, 330, illustration after 350.

42 Williams, History of Negro Troops, 304, 319. The poor treatment of captured soldiers in Union and Confederate prisons obstructed North-South reconciliation throughout the late nineteenth century. On this theme see Benjamin G. Cloud, Haunted by Atrocity: Civil War Prisons in American Memory (Baton Rouge: Louisiana State University Press, 2010).

43 Of course, Confederates believed they were fighting a war for civilization against blacks incapable of civilized behavior and barbarous Yankees determined to destroy their homes.

${ }^{44}$ Gregory J.W. Urwin, ed., Black Flag Over Dixie: Racial Atrocities and Reprisals in the Civil War (Carbondale: Southern Illinois University Press, 2005), 9, 14, 144-145; George S. Burkhardt, Confederate Rage, Yankee Wrath: No Quarter in the Civil War (Carbondale: Southern Illinois University Press, 2007), 131-132, 236-239. 
desire for retaliation but not, he insisted, "in the strict sense of that term, but to fight with a determination to subdue and bring to possible punishment, the men guilty of such atrocious conduct." 45 Williams made the same point in a different way by describing the generous manner in which the black troops had treated their opponents after Lee's surrender at Appomattox. Dividing their rations with paroled Confederates and welcoming them at their camp-fires, he observed, the victors expressed " $[t]$ he sweet gospel of forgiveness." 46 The two soldier-historians thus contrasted notionally Christian southern whites demonstrably capable of heinous brutality with allegedly barbarous black men who had exhibited in victory all the traits associated with genuinely civilized human beings.

As noted above, George Washington Williams and Joseph Wilson were politically active Republicans who saw their texts as contributions to the ongoing black freedom struggle in the United States. Their texts certainly bore traces of their mixed-race origins. Wilson, for example, acknowledged the debt owed by Colored Troops to their white commanders and Williams openly displayed a degree of class-based condescension toward the black masses in the United States by conceding that the majority were "ignorant." ${ }^{47}$ However, both authors clearly understood the importance of establishing their narrative for the benefit of their liberated people. They aimed to educate African Americans about their active contribution to US history in order to contest efforts by white supremacists to undermine black people's pride in their race. The very title of Wilson's book, The Black Phalanx, announced his conception of the USCT as a close-knit formation whose unity had contributed to its effectiveness on the battlefield.

Wilson and Williams singled out one black soldier in particular in order to demonstrate the importance of race pride. André Cailloux was a soldier of color who led a company of the 1st Louisiana Native Guards in an unsuccessful Union assault on Port Hudson on the Mississippi River in May 1863. In spite of being severely wounded in the charge, Cailloux rallied his men and remained in the vanguard until he was torn apart by a Confederate artillery shell. Williams focused not only on his subject's courage under fire but also his self-respect. Captain Cailloux, he wrote, "loved to boast of genuine blackness, and his race pride

45 Wilson, Black Phalanx, 348.

46 Williams, History of Negro Troops, 303.

${ }^{47}$ In dedicating his book to the white officers of USCT regiments, Joseph Wilson acknowledged that those same commanders had taught their men self-restraint. Wilson, Black Phalanx, unnumbered dedication page; Williams, History of Negro Troops, 332. 
made him an acceptable, successful, and formidable leader." 48 Insisting that the "Phalanx soldiers always had a strong race pride," Wilson not only described Cailloux's dramatic final minutes on the battlefield but also recalled witnessing "the funeral pageant of the dead hero" in New Orleans, "the like of which was never seen in that, nor, perhaps, in any other American city, in honor of a dead negro." He also observed that Cailloux's impressive obsequies had announced to local whites the strength of "powerful" black "civic societies." ${ }^{49}$ Wilson and Williams knew from their own experience that racial oppression stymied black progress by placing enormous strains on cooperation between African Americans. As a result they were eager to disseminate the message that race pride and racial unity were essential preconditions for black advancement in the United States.

Both authors intended African American readers to regard Colored Troops as role models for the present - as brave, patriotic, disciplined and proud black men. But determined to resist the consolidation of white supremacy in the form of Jim Crow and knowing the importance of white allies, they also made no secret of their conviction that white Americans too must remember the USCT if the prospect of an interracial republic were not to fade completely. This meant that words alone were not enough to sustain what David Blight refers to as their "emancipationist" memory of the southern rebellion. ${ }^{50}$

Toward the close of his book, Joseph Wilson noted the black soldiers' important financial contributions to the construction of the Freedmen's Memorial to Abraham Lincoln in Washington, DC which had been dedicated in $1876 .{ }^{51}$ Williams went a step further. Aware that white southerners and northerners were busy erecting monuments to their respective causes and that none of the Union monuments commemorated the deeds of black troops who had "helped win the victory," he closed his history by advocating the construction of an imposing monument to those increasingly forgotten men. ${ }^{52}$ This project, he

48 Williams, History of Negro Troops, 218.

${ }^{49}$ Ibid., 214-215, 503.

50 Blight, Race and Reunion, 2.

${ }^{51}$ On the Freedmen's Memorial to Abraham Lincoln in Washington see Kirk Savage, Standing Soldiers, Kneeling Slaves: Race, War, and Monument in Nineteenth-Century America (Princeton: Princeton University Press, 1997), 90-92. The monument, funded entirely by African Americans (including many USCT), depicts President Lincoln raising up an enslaved man who is prone but breaking free from his chains. It remains controversial with Black Lives Matter protesters today. See David Blight's call for it to be retained: "Yes, the Freedmen's Memorial uses racist imagery. But don't tear it down,” The Washington Post, June 25, 2020, https://www.washingtonpost.com/ opinions/2020/06/25/yes-freedmens-memorial-uses-racist-imagery-dont-tear-it-down/.

52 Williams, History of Negro Troops, 327. 
insisted, should be a national one - a congressionally funded monument to those black soldiers who had fought and in many cases died "in the struggle for national existence." Such a monument, he ventured, "would surely elevate the Negro to a proud place in the history of the nation ... [A] republic that remembers to defend its defenders in tracing their noble conduct in monumental marble and brass can never decay." 53

\section{Reception}

The "emancipationist" accounts of George Washington Williams and Joseph Wilson were essentially race-centered variants of the once robust victors' memory of the Civil War. White northerners, Union veterans most prominent among them, were the primary architects of this memory. It prioritized two achievements: first, the saving of the nation from its southern enemies, and second, the destruction of slavery which, the majority of white northerners concurred, had been the chief source of what they regarded as the slaveholders' wicked rebellion against the United States. ${ }^{54}$ This strain of Civil War memory was still a political and cultural force in the late 1880s. Indeed, the death of Confederate president Jefferson Davis in December 1889 gave it a new lease of life because many northerners were horrified at the sight of so many southerners mourning a man widely regarded above the Mason-Dixon Line as the mastermind behind secession. ${ }^{55}$ However, by this date Unionist memories of the "War of the Rebellion" were rapidly losing their power because they demonized fellow Americans at a time when Civil War issues seemed irrelevant to people dealing with life in a highly competitive and increasingly industrialized society. While many Republicans had resisted the sentimental pull of sectional reconciliation during and even after Reconstruction, party leaders were more and more reluctant to be seen to be stoking national divisions for the sake of protecting southern blacks. In early

53 Ibid., 328, 332.

${ }^{54}$ Although historian Gregory J. W. Urwin, Black Flag Over Dixie, 4, contends that "[t]he aging boys in blue celebrated their war as a crusade to save the Union and ignored the fact that it also destroyed slavery," white Union veterans regularly vaunted their practical contribution to the destruction of slavery in their memoirs and commemorative exercises. See Robert Hunt, The Good Men Who Won the War: Army of the Cumberland Veterans and Emancipation Memory (Tuscaloosa: University of Alabama Press, 2010), 20-33, and Harris, Across the Bloody Chasm, 108-113.

55 Robert J. Cook, "'Not Buried Yet': Northern Responses to the Death of Jefferson Davis and the Stuttering Progress of Sectional Reconciliation," Journal of the Gilded Age and Progressive Era 18, No. 3 (July 2019): 324-348, doi: 10.1017/S1537781419000045. 
1891 a handful of Republican senators from the Far West helped defeat their party's last serious effort to enforce the constitutional right of black men to vote in the South. ${ }^{56}$ This issue would not feature prominently on the political agenda of both major parties in the United States again until debates over new voting rights legislation in the late 1950s.

Although some white northerners, notably a minority of Union veterans, did not forget the Colored Troops' loyal service, Richard Hinton expressed a potent countervailing view in Belford's Magazine in December 1889.57 Hinton - a former abolitionist disillusioned by the fact that the US government had intervened militarily to protect black voters during Reconstruction - insisted that black folk had been passive actors in the Civil War and that they had failed to take advantage of the opportunities provided by emancipation. The USCT, he wrote, "were men of the intelligence of children and the docility of babes. They would march steadily into battle, and remain fighting as long as their [white] officers led them. This is not the material of, or foundation on, which republics are built." African Americans, he added gratuitously, lacked the manhood to look after themselves and the science of evolution left them "with the monkey." 58 Tellingly, Hinton's dim view of African Americans in wartime was replicated by contributors to the country's growing roster of amateur magazines written by and for young people. Young northern writers rarely mentioned the USCT in their accounts of the Civil War, preferring instead to praise Confederate general Robert E. Lee as a model American, to make "faithful darkeys" the lackeys of Union soldiers, and even to cast doubt on the wisdom of emancipation. ${ }^{59}$

The two USCT histories were probably read primarily, though not exclusively, by African Americans, largely because East Coast publishers looked to market the texts in black communities across the northern states and the former Confederacy. The country's black press generally praised them but reviews

56 Cook, Civil War Memories, 92-93.

${ }^{57}$ For evidence of some white Union veterans' continuing support for black civil rights after Reconstruction see Hunt, Good Men, 88-89; William H. Armstrong, Major McKinley: William McKinley and the Civil War (Kent, OH: Kent State University Press, 2000), 113-114; Cook, Civil War Memories, 93.

58 Richard J. Hinton, "Negro Enlistments and the Negro Element," Belford's Magazine 2, No. 12 (December 1889): 866.

59 “Slavery," The Correspondent (Newburyport, MA), August 1879; "Castie, '61-'65: A Narrative of the Late Civil War," The Patriot (Detroit), February 20, 1881; Edwin Harris, "Two Great Men," Punch, 1884; Will C. Brown, "Robert E. Lee," Clio (Worcester, MA), September 1886. These magazines can be found in the online Gale collection of Amateur Newspapers from the American Antiquarian Society: https://www.gale.com/c/amateur-newspapers-from-the-american-antiquarian-society. 
sometimes contained bitter comments on whites' treatment of the race since 1865. One writer described The Black Phalanx as "a volume valuable to all Negro homes," adding that African Americans had long desired a study "of our works in the late rebellion and in the free movements in this country as efforts are ceaselessly made to impress us with the fact that we have helped ourselves but little towards freedom." 60 Another review - in a Kansas newspaper - blamed local Republicans for betraying black people in the years after liberation. "[T] he Black Phalanx," wrote the author, "fought with the courage and principals [sic] of good loyal citizens" in the Civil War but in the last election so-called Republicans had described black people as "coons, niggars [sic], wenches etc. ... You are Republicans, but hell is full of just such as you are and what few of you are left here on earth, have all collected here in Leavenworth." 61

Reviews also appeared in many mainstream newspapers, secular magazines and religious journals. As John David Smith shows in his introduction to a modern edition of Williams' book, they ranged from broadly positive to highly critical. ${ }^{62}$ Joseph E. Roy, a Congregationalist minister, penned one of the warmest commentaries. Asserting that Williams recounted the story of the USCT with "wondrous effect," Roy reminded the well-to-do readers of the New Englander and Yale Review that "the black man faltered not in his patriotism" during the late conflict. Americans, he added, "are under obligation, not only to see that our Government makes good its covenant with the negroes, but to go on with the means of Christian enlightenment in order to help them maintain their rights, to make them the best possible citizens of this nation, our's and their's." 63 Other white reviewers, more inclined than Roy to highlight the texts' undoubted flaws, were not only less positive but they also ignored Roy's insistence that Americans owed black folk a debt for their wartime loyalty to the government. "Both books," asserted a condescending review in the Nation, "show honest intentions and a certain amount of praiseworthy diligence ... but both show a want of method and an inability to command their own materials, so that they leave the reader with a renewed interest in the subject, but with a very imperfect sense of clear comprehension." 64

60 The Cleveland Gazette, February 18, 1888.

61 The American Citizen (Topeka), December 4, 1888.

${ }^{62}$ Smith, Introduction to A History of Negro Troops, xxvi-xxix.

${ }^{63}$ Joseph E. Roy, "Our Indebtedness to the Negroes for Their Conduct during the War," New Englander and Yale Review 15, No. 236 (November 1889): 356, 362, 363.

64 Quoted in Franklin, George Washington Williams, 131. 
The Civil War texts of Williams and Wilson were part of a much broader effort by African Americans throughout the late nineteenth century to inscribe themselves, in the words of historian Steven Kantrowitz, "into the national narratives of democracy and fraternity." 65 This effort encompassed many different narrative strategies including that of Booker T. Washington whose famous Atlanta address in 1895 embraced a central trope of the Lost Cause by reimagining emancipated blacks as faithful slaves. ${ }^{66}$ The fact that none of these strategies were able to halt the national spread of Jim Crow said far more about the virulence of white racism at this time than the relative strengths and weaknesses of the strategies themselves. The black soldier-historians' inability to sustain a national memory of the USCT, however, was linked specifically not only to most white northerners' refusal to grant African Americans a significant part in the Unionist narrative of the Civil War but also to that narrative's waning influence in the late 1880s and 1890s as sectional notions of the War of the Rebellion faded under pressure for an affective rapprochement between white northerners and southerners. One illustration of their inability to write the USCT into national history was the fact that Williams' innovative proposal for the building of a national monument to the USCT came to naught. Although he did help to draft a bill to fund construction, testified in its favor before a congressional committee and lobbied Union veterans of both races to petition their delegates to sign it into law, the measure eventually died in the House of Representatives after passing the Senate in December $1887 .{ }^{67}$ Lacking the money to build monuments of their own, African Americans would have to wait more than a century for construction in Washington of a dedicated memorial to black Union troops. ${ }^{68}$

After the defeat of voting rights legislation in 1891 most leading Republicans embraced sectional reconciliation at the expense of equal rights for African Americans. Some white Union veterans, angered by the US government's unwillingness or inability to protect the rights of their black comrades, did support Albion Tourgée's abortive attempt to create a national civil rights organization in the early $1890 \mathrm{~s} .{ }^{69} \mathrm{By}$ the end of this decade, however, white southerners, further

65 Steven Kantrowitz, More than Freedom: Fighting for Black Citizenship in a White Republic 18291889 (Penguin Press: New York, 2012), 5.

${ }^{66}$ Cook, Civil War Memories, 117-118.

67 Blight, Race and Reunion, 196-197.

68 The congressionally-funded African American Civil War Memorial was dedicated in the Shaw neighborhood of Washington, DC in 1998. Cook, Civil War Memories, 188.

69 Tourgée was a white Union veteran heavily invested in the postwar struggle for equal rights for African Americans. On his ill-fated civil rights project see Mark Elliott, Color-Blind Justice: Albion Tourgée and the Quest for Racial Equality from the Civil War to Plessy v. Ferguson (New York: Ox- 
abetted by the Supreme Court's pro-segregation ruling in the landmark case of Plessy v. Ferguson (1896) as well as consensual pressures induced by the country's war against Spain in 1898, had made the United States a Jim Crow nation.

\section{Constructing an African American Counter-Memory}

While the memory work of Joseph Wilson and George Washington Williams was far from unproblematic, it contributed directly to the construction of a durable African American counter-memory of the Civil War era. Preoccupied with linking masculine performance in the military service of the nation to the attainment of equal citizenship, the two soldier-historians not only erased evidence of black vengeance against Confederates but also passed over the wartime role of African American women. As historian Thavolia Glymph has shown, black women played an active role in the defense of the United States during the Civil War but were elided from most Unionist accounts of the conflict.70 Impoverished, denigrated and disempowered as many black women were in the late nineteenth century, they hardly needed their own menfolk to press the case for equal citizenship on the basis of a gendered martial patriotism from which they were, by definition, excluded. Nevertheless, notwithstanding their selective use of evidence and ultimate inability to remind white Americans of the major role played by black soldiers in saving the republic, the two historians' emphasis on black courage, loyalty to the government and race pride impressed many African Americans in the late nineteenth and early twentieth century, even as growing numbers of black folk became disenchanted with the unfulfilled promise of emancipation and began to embrace Booker T. Washington's controversial accommodationist strategy. A major test of a counter-memory's effectiveness is its impact on the oppressed - the extent to which it enables disempowered individuals and groups to maintain not only a sense of self-respect but also a conviction that they can change society in the present because it has proved mutable in the past. In this respect the black veterans' histories helped to lay the foundations of a genuinely usable past as it was laid down most famously by W.E.B. Du Bois.

ford University Press, 2006), 252-259, 261, 266, 273-277, 295, and Carolyn L. Karcher, A Refugee from His Race: Albion W. Tourgée and His Fight against White Supremacy (Chapel Hill: University of North Carolina Press, 2016), 149-195.

70 Thavolia Glymph, “'I'm a Radical Black Girl:' Black Women Unionists and the Politics of Civil War History," Journal of the Civil War Era 8, No. 3 (September 2018): 359-387, doi: 10.1353/ cwe.2018.0047. 
John Hope Franklin, the African American biographer of George Washington Williams who acknowledged his subject's influence on his own work, intimated that the aspiring members of the Indianapolis Reading Circle read and discussed the History of Negro Troops. ${ }^{71}$ It is likely that many African Americans who belonged to local uplift groups like this one were equally familiar with Wilson's book which, according to one black newspaper, attained "the largest sale of any book written by an American Negro."72 Du Bois, a pioneering sociologist and skilled historian, admired the two soldier-historians' determination to make African Americans central to the national story and drew on their writings to make the same point himself. Convinced, as he argued in a 1909 biography of the revolutionary white abolitionist John Brown, that violence had been necessary to destroy North American slavery, he included a black Civil War soldier in the cast of his spectacular historical pageant, The Star of Ethiopia, which was performed in New York City in 1913 as part of the National Emancipation Exposition. ${ }^{73}$ Audiences heard the character announce that: "I represented Ethiopia in the Civil War. I am a Union soldier. I fought for Old Glory. Who says that Ethiopia has done nothing for civilization? When civilization was about to fail in America, Ethiopia saved it." ${ }^{\prime 4}$ Du Bois referenced the USCT in his global history of black people, The Negro, which appeared two years later. Citing the work of both Wilson and Williams in his chapter on the United States, he recounted the Colored Troops' "exemplary conduct" in the Civil War as well as the "barbarous" treatment of captured black soldiers at places like Fort Pillow. He also followed their narrative strategy by quoting white authorities on the heroism and importance of these men and describing the attack on Fort Wagner as "one of the greatest deeds of desperate bravery on record." 75 It is likely that Du Bois's decision in the summer of 1918 to urge black men to enlist in the US armed forces during World War I was influenced by the fact that the loyalty and bravery of the USCT had prompted watershed federal initiatives like the Fourteenth and Fifteenth

71 Smith, Introduction to A History of Negro Troops, x; Franklin, George Washington Williams, 133.

72 Huntsville Gazette, December 1, 1888. The newspaper provided no evidence to bolster its assertion.

${ }^{73}$ W.E.B. Du Bois, John Brown (Philadelphia: George W. Jacobs \& Company, 1909). Du Bois insisted (386) that "the memory of John Brown stands to-day as a mighty warning to his country." The biography also included a chapter on antebellum black abolitionists entitled "The Black Phalanx."

74 Quoted in William H. Wiggins, Jr., O Freedom! Afro-American Emancipation Celebrations (Knoxville: University of Tennessee Press, 1987), 59.

75 W.E.B. Du Bois, The Negro (New York: Holt, 1915). These citations are from the 2005 Project Gutenberg text at https://ia800708.us.archive.org/4/items/thenegro15359gut/15359-8.txt. This edition does not contain page references. 
Amendments to the Constitution. If black men's patriotism had levered government assistance for African Americans in the 1860s, why could it not do so again in 1917?

Du Bois had close personal experience of the viciousness of American racism in the early twentieth century - he had been teaching in Atlanta at the time of the city's 1906 race massacre - and should probably have known better. His closeranks strategy was certainly controversial, even with former allies like Monroe Trotter who saw no reason why blacks should volunteer to fight for a country that oppressed them. ${ }^{76}$ It failed partly because white Americans were no longer divided over slavery and secession as they had been during the Civil War. Assisted by commentators like Richard Hinton, they had either long forgotten or did not care that black men had helped to save the republic and, as the nationwide popularity of D. W. Griffith's epic movie, The Birth of a Nation (1915), revealed, they were enthusiastic consumers of popular narratives of the Civil War that exacerbated domestic racism. Instead of prompting fresh federal initiatives to assist marginalized African Americans, black men's enlistment in World War I culminated in a lethal surge of white-supremacist violence directed against black people across the United States. In June $1919 \mathrm{Du}$ Bois admitted that black involvement in the war had resulted in the "frank realization" that the duty of America "as conceived by an astonishing number of able men, brave and good, as well as other sorts of men, is to hate 'niggers." 77 From this point on, he joined other black historians working in the rigidly segregated milieu of the 1920s and 1930s to fashion a robust counter-narrative of the American past that centered on Reconstruction rather than on the loyalty, heroism and discipline of the USCT.

Du Bois's decision to target Reconstruction rather than the Civil War made sense after 1918. First, the decision acknowledged the centrality of Reconstruction memories to the political and social oppression of African Americans in the Jim Crow era. White scholars like William A. Dunning of Columbia University and Woodrow Wilson of Princeton had consolidated the belief, nationwide by the late nineteenth century, that Reconstruction had been a dismal failure because liberated black men had been unfit to exercise political power over whites in the late $1860 \mathrm{~s}$ and $1870 \mathrm{~s}^{78}$ Southern politicians regularly remind-

${ }^{76}$ Ronald R. Krebs, Fighting for Rights: Military Service and the Politics of Citizenship (Ithaca: Cornell University Press, 2006), 124-125.

77 W.E.B. Du Bois, "An Essay Toward a History of the Black Man in the Great War," Crisis 18, No. 2 (June 1919): 63.

78 Peter Novick, That Noble Dream: The "Objectivity Question" and the American Historical Profession (New York: Cambridge University Press, 1988), 72-80. 
ed their white constituents of the supposed horrors of "black rule" in order to strengthen their own position and foster intraracial unity in the service of the regionally dominant Democratic party. ${ }^{79}$ Most white northerners, avid consumers in the interwar period of powerful fictions like Birth of a Nation and Gone With the Wind which demonized Reconstruction, had no reason to challenge the dominant narrative. However, Du Bois and other black scholars, notably Carter G. Woodson, the founder of the Association for the Study of Negro Life and History (ASNLH) in 1915, understood that the master narrative sustained white supremacy by denigrating the only period in American history when African Americans had exercised a measure of genuine political power. ${ }^{80}$ Their response was to construct a viable counter-narrative of the Civil War era that directly challenged white assumptions. Du Bois's classic Black Reconstruction in America (1935), a Marxist interpretation of the turbulent postwar period, sought to undermine myths about black passivity and incompetence in the same way as the older histories of Williams and Wilson had tried to remind black and white readers, contrary to the view of commentators like Richard Hinton, that African Americans had played a leading role in their own liberation. ${ }^{81}$

Although black historians in the 1880s and 1920s/1930s dealt with different (though linked) historical subjects, their work was connected by a common stress on black agency in the American past. ${ }^{82}$ Williams and Wilson focused tightly on the patriotic actions of armed black men in the war to save the Union. The work of their successors embraced a broader section of the black community and thereby laid the foundations for a more inclusive usable past. Du Bois hailed the contribution of enslaved black workers to the collapse of slavery and the Confederacy and went on to detail the effectiveness and progressive nature of

${ }^{79}$ Bruce E. Baker, What Reconstruction Meant: Historical Memory in the American South (Charlottesville: University of Virginia Press, 2007), 95-102; Nina Silber, This War Ain't Over: Fighting the Civil War in New Deal America (Chapel Hill: University of North Carolina Press, 2018), 140-142.

${ }^{80}$ Woodson's efforts to sustain and disseminate a counter-memory of the African American past are detailed in Jacqueline Goggin, Carter G. Woodson: A Life in Black History (Baton Rouge: Louisiana State University Press, 1993).

81 W.E.B. Du Bois, Black Reconstruction: An Essay toward a History of the Part which Black Folk Played in the Attempt to Reconstruct Democracy in America, 1860-1880 (New York: Harcourt, Brace, 1935).

82 African American historians' relative lack of interest in the Civil War after World War I is evidenced by the fact that the ASNLH's Journal of Negro History published only two articles relating to the USCT between 1915 and 1941. These were both written by white scholars: Fred A. Shannon, "The Federal Government and the Negro Soldier, 1861-1865," Journal of Negro History 11, No. 4 (October 1926): 563-583, and Brainerd Dyer, "The Treatment of Colored Union Troops by the Confederates, 1861-1865," Journal of Negro History 20, No. 3 (July 1935): 273-286. 
Reconstruction-era governments in which African Americans had played a leading role. Instructively, however, in chapter five of Black Reconstruction, "The Coming of the Lord," Du Bois recounted the "spectacular revolution" unleashed by the Civil War by drawing repeatedly on the writings of Wilson and Williams to demonstrate how the enslaved became self-liberators. ${ }^{83}$ "Nothing else made Negro citizenship conceivable," he wrote, "but the record of the Negro soldier as a fighter." To make the point he illustrated the heroism of black troops at Port Hudson, singling out, as the two soldier-historians had done before him, "Captain Cailloux of the 1st Louisiana, a man so black that he actually prided himself upon his blackness" and who "died the death of a hero, leading on his men in the thick of the fight." In the same chapter Du Bois also followed Wilson and Williams by using the Fort Pillow massacre, "[t]he most terrible case of Confederate cruelty," to demonstrate the capacity of home-grown white supremacists for the most appalling violence.

Like the Civil War histories of black Union veterans, the studies of Du Bois, Carter Woodson, and Woodson's students like Alrutheus A. Taylor, focused though they were primarily on postwar Reconstruction, documented black people's active contribution to their own freedom as well as to the wider American community. ${ }^{84}$ Just like the histories of the USCT written in the late 1880 s, they had only a marginal impact on the dominant views of the white majority (communist scholars like Herbert Aptheker were the main exception in Du Bois's case). However, they too fostered intraracial commitment to political change by supplying African Americans with compelling evidence that the prevailing view of the national past was a witting fraud perpetrated by white politicians, historians, novelists and film-makers.

Although the crusading civil rights and Black Power movements of the 1960s came too late for Du Bois and other pioneering black scholars, those movements' considerable enhancement of African American cultural influence at the local and national level belatedly brought the counter-memory to the attention of increasing numbers of whites. ${ }^{85}$ By the 1980 s the concept of black agency

83 Chapter five of Black Reconstruction contained ten citations from the Civil War segment of Williams' History of the Negro Race in America and fifteen from Wilson's Black Phalanx. The quotations from Black Reconstruction in this paragraph are taken from the online Internet Archive edition of the book available at https://libcom.org/files/black_reconstruction_an_essay_toward_a_history_of_.pdf. This edition does not contain page references.

84 Blight, "W.E.B. Du Bois," 57-63; Baker, What Reconstruction Meant, 113-117,123-125.

85 White American historians belatedly rediscovered the USCT in the midst of what C. Vann Woodward referred to as "the New Reconstruction" in The Strange Career of Jim Crow (New York: Oxford University Press, 1955), 9. Admitting that he did not know about their existence until he 
explored so vigorously a hundred years previously by the black soldier-historians had fundamentally altered the way mainstream American scholars wrote about their country's past - its influence most notable in Eric Foner's sweeping history of Reconstruction which placed liberated black folk at the center of the story. ${ }^{86}$ However, white supremacists in the United States still seek to perpetuate old myths about the beneficence of American slavery and the latter's negligible role in the coming of the Civil War. The residual power of those myths is perhaps most evident in President Trump's politically-charged hostility, evidenced by his refusal to condemn neo-Nazi and neo-Confederate violence in Charlottesville in 2017 as well as his open contempt for the 1619 Project, to any story of the American past centered on the country's long history of prejudice against people of color. Manifestly, the present-focused challenge that confronted George Washington Williams and Joseph Wilson - to render African Americans vital players in the republic's past - remains as pressing today as it was in the late nineteenth century.

entered graduate school, Dudley Taylor Cornish wrote the first comprehensive modern history of the USCT in 1956. While noting his debt to Wilson and Williams, Cornish criticized their texts for suffering "the common faults of weak organization, lack of documentation, lack of objectivity, and a constant tendency toward extravagant praise of Negro soldiers." Cornish, Sable Arm, 317. Assisted by the burgeoning civil rights movement, Cornish's book triggered new interest in the USCT. In 1962 a progressive white Republican lawyer, Howard N. Meyer, secured republication of Thomas Wentworth Higginson's Army Life in a Black Regiment (1870), one of the most revealing memoirs written by a white USCT officer. "Two hundred thousand Negroes fought in that war," commented Meyer, "but you never hear of them. We buried their achievements, as we buried those of other leading Negroes immediately after the war, when we defeated slavery but accepted segregation." Quoted in Robert J. Cook, Troubled Commemoration: The American Civil War Centennial, 1961-1965 (Baton Rouge: Louisiana State University Press, 2007), 168, note 32. W.W. Norton issued a paperback edition of Cornish's history in 1966. These books laid the groundwork for later academic scholarship on the black military experience in the Civil War (see note 23 above). But popular interest in the USCT was not genuinely piqued until the appearance of Edward Zwick's Hollywood movie, Glory, in 1989.

${ }^{86}$ Eric Foner, Reconstruction: America's Unfinished Revolution 1863-1877 (New York: Harper \& Row, 1988). Black agency in the Civil War and the postwar era is also the central theme of Steven Hahn, A Nation Under Our Feet: Black Political Struggles in the Rural South from Slavery to the Great Migration (Cambridge, MA: Belknap Press of Harvard University Press, 2003). 